\title{
PENGARUH PERUBAHAN PENGGUNAAN LAHAN \\ TERHADAP ANGKA KESAKITAN MALARIA : STUDI DI PROVINSI LAMPUNG
}

\section{(EFFECT OF LAND USE CHANGES TOWARD MALARIA MORBIDITY: STUDY IN LAMPUNG PROVINCE)}

\author{
Lirih Wigaty $^{1)}$, Samsul Bakri ${ }^{2)}$, Trio Santoso ${ }^{2)}$, dan Dyah Wulan S. R. Wardani ${ }^{3)}$ \\ ${ }^{1)}$ Mahasiswa Jurusan Kehutanan Fakultas Pertanian Universitas Lampung \\ ${ }^{2}$ Dosen Jurusan Kehutanan Fakultas Pertanian Universitas Lampung \\ ${ }^{3)}$ Dosen Bagian Ilmu Kesehatan Masyarakat Fakultas Kedokteran Universitas Lampung \\ Jl. Soemantri Brojonegoro no.1 Bandar Lampung \\ E-mail : lirihwigaty@gmail.com No. Telepon : 085669478985
}

\begin{abstract}
ABSTRAK
Gangguan ekologi sebagai akibat perubahan tutupan hutan menjadi penggunaan lahan lainnya dapat mempengaruhi iklim mikro dan berdampak terhadap angka kesakitan malaria. Malaria merupakan penyakit yang disebabkan infeksi protozoa dari genus Plasmodium melalui vektor nyamuk betina Anopheles sp. Faktor lingkungan berperan dalam resiko penularan malaria berkaitan dengan habitat perkembangbiakan vektor. Tujuan penelitian ini adalah menetapkan pengaruh perubahan penggunaan lahan terhadap angka kesakitan malaria. Penelitian dilakukan mulai bulan Maret-September 2015. Dinamika perubahan penggunaan lahan tiap kabupaten/kota diidentifikasi melalui interpretasi citra landsat tahun 2002, 2009, dan 2014 dengan metode klasifikasi terbimbing dan menghasilkan persentase luas penggunaan lahan, sedangkan dampaknya terhadap angka kesakitan malaria dianalisis menggunakan model regresi linier berganda. Optimasi parameter model menggunakan software statistik. Hasil penelitian membuktikan bahwa variabel yang berpengaruh nyata positif terhadap angka kesakitan malaria yaitu luas hutan mangrove dan jumlah penduduk, sedangkan variabel yang berpengaruh nyata negatif yaitu luas rawa dan tenaga kesehatan. Variabel yang tidak berpengaruh nyata terhadap angka kesakitan malaria antara lain hutan negara, hutan rakyat, lahan terbangun, lahan kering, penggunaan lain, kepadatan penduduk, curah hujan, rumah tak layak, urbanisme, dan fisiografis.
\end{abstract}

Kata kunci : penggunaan lahan, angka kesakitan malaria

\section{ABSTRACT}

Ecological disruption as a result of changes in the area of forest cover to other land uses can affect the microclimate and impact toward malaria morbidity. Malaria is an infectious disease caused by protozoa a genus of Plasmodium that transmitted by female Anopheles sp. mosquito vectors. The environmental factors that play a role in the risk to transmission of malaria related to vector breeding places. The purpose of this research is establish the impact of land use changes toward malaria morbidity. This study was conducted from March to September 2015. Dynamics of land use changes in regency/city be identified through interpretation of landsat imagery in 2002, 2009, and 2014 with supervised classification and resulted in percentage of land use, the influence of impact toward malaria morbidity processed using multiple linear regression models. Parameter optimization using statistic software. The result showed that the impact of positive variable that significant toward malaria morbidity are mangrove forest and total population, while impact of negative variable that significant are extensive swamp and health 
personnel. Variable which not impact that significant toward malaria morbidity are forests, community forests, undeveloped land, dry land, other land uses, population density, precipitation, unhealthyhousing, urban, and physiographic.

Keywords : land use, malaria morbidity

\section{PENDAHULUAN}

Desentralisasi tata kelola kehutanan telah berdampak pada degradasi dan deforestasi hutan yang akut. Berdasarkan data Kementerian Kehutanan (2013) di Provinsi Lampung angka deforestasi di dalam kawasan hutan periode 2010-2012 (ha/th) untuk hutan produksi sebesar 517,5 ha, Kawasan Suaka Alam dan Kawasan Pelestarian Alam sebesar 13,2 ha, dan Areal Penggunaan Lain sebesar 9,9 ha. Tidak dapat dipungkiri bahwa degradasi dan deforestasi hutan juga diiringi dengan pertumbuhan ekonomi yang didorong pertumbuhan dari sektor industri. Namun pertumbuhan ekonomi yang dilandasi oleh perubahan land use dari korbanan tutupan hutan ke penggunaan lahan disisi lain juga berdampak pada kemerosotan fungsi ekologis wilayah.

Gangguan ekologis akibat perubahan iklim memiliki pengaruh besar terhadap penyakit yang ditularkan melalui vektor salah satunya malaria. Malaria merupakan penyakit yang disebabkan oleh infeksi protozoa dari genus Plasmodium yang ditularkan melalui vektor nyamuk betina Anopheles sp. Salah satu faktor lingkungan yang berperan dalam risiko penularan malaria adalah berkaitan dengan habitat perkembangbiakan. Di Indonesia menurut laporan World Health Organization (WHO) 2009 dalam Raharjo (2011) malaria merupakan sepuluh besar penyakit di Indonesia.

Berdasarkan data Profil Kesehatan Provinsi Lampung tahun 2013, Provinsi Lampung merupakan salah satu daerah endemis malaria karena mempunyai wilayah yang berpotensi sebagai tempat berkembangnya nyamuk malaria. Untuk menghitung jumlah kasus yang terjadi pada periode tertentu ukuran yang digunakan untuk mengukur frekuensi angka kesakitan adalah indikator Annual Parasite Incidence (API).

Perubahan ekologis lebih lanjut berdampak pada kesehatan masyarakat. Perubahan iklim mikro dapat menekan ketahanan manusia terhadap penyakit malaria. Kelompok masyarakat dengan kapasitas beradaptasi rendah akan semakin rentan terhadap berubahnya pola distribusi penyakit yang ditularkan melalui vektor. Semua ini dapat meningkatkan intensitas penyakit malaria pada masyarakat sebagai resultan akhir dari perubahan proporsi tutupan hutan ke penggunaan lahan lainnya. Atas dasar latar belakang tersebut, tujuan dari penelitian ini adalah menetapkan pengaruh perubahan penggunaan lahan terhadap angka kesakitan malaria di Provinsi Lampung.

\section{METODE PENELITIAN}

Penelitian ini dilakukan di Laboratorium Inventarisasi dan Pemetaan Hutan Jurusan Kehutanan Fakultas Pertanian Universitas Lampung. Penelitian dimulai dari MaretSeptember 2015. Data primer yang digunakan dalam penelitian ini berupa citra landsat path 123/124 row 063/064 tahun 2002, 2009, dan 2014 dan data sekunder pendukung antara lain angka kesakitan API, kepadatan penduduk, jumlah penduduk, curah hujan, tenaga kesehatan, dan rumah tak layak yang diperoleh dari instansi terkait.

Penelitian ini merupakan bagian dari payung penelitian tentang dampak deforestasi dan degradasi sumber daya hutan terhadap angka kesakitan beberapa penyakit, produktifitas, dan kesejahteraan masyarakat di Provinsi Lampung (Bakri dkk, 2015). Pada prinsipnya ada dua bagian besar dalam penelitian ini yaitu akuisisi data variabel terikat dan 
variabel bebas. Variabel terikat (Yi) berupa angka kesakitan malaria per kabupaten/kota di Provinsi Lampung tahun 2000-2014 yang disajikan dalam satuan intensitas kejadian per 1000 penduduk. Data variabel bebas (X) terdiri dari data penggunaan lahan (hutan negara, hutan rakyat, hutan mangrove, rawa, lahan terbangun, lahan kering, dan penggunaan lain) dan data sekunder pendukung.

Data penggunaan lahan akan diinterpretasi melalui software Sistem Informasi Geografis (SIG) dengan metode klasifikasi terbimbing dan menghasilkan peta land use terinci. Setelah diperoleh data variabel bebas (X) dan data variabel terikat (Y) akan dilakukan analisis regresi linier berganda untuk menetapkan besarnya kontribusi perubahan penggunaan lahan terhadap angka kesakitan malaria. Dalam penelitian ini analisis data yang digunakan adalah persamaan regresi linier berganda dengan model sebagai berikut sedangkan keterangan variabel, simbol, satuan dan skor, sumber data disajikan dalam Tabel 1.

$$
\begin{aligned}
& {[\mathrm{Y}]_{\mathrm{it}}=\alpha_{0}+\alpha_{1}[\mathrm{HN}]_{\mathrm{it}-1}+\alpha_{2}[\mathrm{HR}]_{\mathrm{it}-1}+\alpha_{3}[\mathrm{MRV}]_{\mathrm{it}-1}+\alpha_{4}[\mathrm{RW}]_{\mathrm{it}-1}+\alpha_{5}[\mathrm{LTER}]_{\mathrm{it}-1}} \\
& +\alpha_{6}[\mathrm{LK}]_{\mathrm{it}-1}+\alpha_{7}[\mathrm{PL}]_{\mathrm{it}-1}+\alpha_{8}[\mathrm{CH}]_{\mathrm{it}-1}+\alpha_{9}[\mathrm{KPD}]_{\mathrm{it}}+\alpha_{10}[\mathrm{JPD}]_{\mathrm{it}} \\
& +\alpha_{11}[\mathrm{TKS}]_{\mathrm{it}}+\alpha_{12}[\mathrm{RTL}]_{\mathrm{it}}+\alpha_{13}\left[\mathrm{D}_{1-} \mathrm{URBAN}\right]+\alpha_{14}\left[\mathrm{D}_{2-} \mathrm{PGN}\right]+e
\end{aligned}
$$

\section{Hipotesis Model}

\begin{tabular}{|c|c|c|c|c|}
\hline No & Variabel & Simbol & Satuan dan Skor & Sumber \\
\hline 1 & API & {$[\mathrm{Y}]$} & Per 1000 penduduk & Dinas Kesehatan Provinsi Lampung \\
\hline 2 & Hutan negara & {$[\mathrm{HN}]$} & $\%$ & Interpretasi citra landsat \\
\hline 3 & Hutan rakyat & [HR] & $\%$ & Interpretasi citra landsat \\
\hline 4 & Hutan mangrove & {$[\mathrm{MRV}]$} & $\%$ & Interpretasi citra landsat \\
\hline 5 & Rawa & {$[\mathrm{RW}]$} & $\%$ & Interpretasi citra landsat \\
\hline 6 & Lahan terbangun & [LTER] & $\%$ & Interpretasi citra landsat \\
\hline 7 & Lahan kering & {$[\mathrm{LK}]$} & $\%$ & Interpretasi citra landsat \\
\hline 8 & Penggunaan Lain & {$[\mathrm{PL}]$} & $\%$ & Interpretasi citralandsat \\
\hline 9 & Kepadatan penduduk & [KPD] & jiwa/km² & BPS Provinsi Lampung \\
\hline 10 & Jumlah penduduk & [JPD] & jiwa & BPS Provinsi Lampung \\
\hline 11 & Curah hujan & {$[\mathrm{CH}]$} & $\mathrm{mm} / \mathrm{th}$ & Dinas Bina Marga \\
\hline 12 & Tenaga kesehatan & [TKS] & jiwa & BPS Provinsi Lampung \\
\hline 13 & Rumah tak layak & [RTL] & KK & BPS Provinsi Lampung \\
\hline 14 & Urbanisme & [D $\left.\mathrm{D}_{1} \mathrm{URBAN}\right]$ & Dummy & Center for Soil Research \\
\hline 15 & Fisiografis & {$\left[\mathrm{D}_{2} \mathrm{PGN}\right]$} & $\begin{array}{r}1=\text { Kota, } 0=\text { lainnya } \\
\text { Dummy } \\
1=\text { Pegunungan, } \\
0=\text { lainnya }\end{array}$ & Center for Soil Research \\
\hline
\end{tabular}

$$
\begin{aligned}
& \mathrm{H}_{0}=\alpha_{1}=\alpha_{2}=\alpha_{3}=\alpha_{4}=\alpha_{5}=\alpha_{6}=\alpha_{7}=\alpha_{8}=\alpha_{9}=\alpha_{10}=\alpha_{11}=\alpha_{12}=\alpha_{13}=\alpha_{14}=0 \\
& \mathrm{H}_{1}=\alpha_{1} \neq \alpha_{2} \neq \alpha_{3} \neq \alpha_{4} \neq \alpha_{5} \neq \alpha_{6} \neq \alpha_{7} \neq \alpha_{8} \neq \alpha_{9} \neq \alpha_{10} \neq \alpha_{11} \neq \alpha_{12} \neq \alpha_{13} \neq \alpha_{14}=0
\end{aligned}
$$

Tabel 1. Variabel, simbol, satuan dan skor, sumber data.

Optimasi parameter model dengan menggunakan software statistik. Signifikansi pengaruh variabel independen terhadap variabel dependen dalam model tersebut akan digunakan uji T. Sedangkan uji masing-masing variabel independen terhadap variabel dependen akan digunakan uji F pada taraf nyata $10 \%$.

\section{HASIL DAN PEMBAHASAN}

Kejadian malaria dengan menggunakan indikator API tahun 2003, 2010, dan 2014 di Provinsi Lampung maksimum 2,32 per 1000 penduduk dan minimum 0,00 per 1000 penduduk serta rata-rata kejadian malaria 0,35 per 1000 penduduk. Berikut grafik angka 
kesakitan API per kabupaten/kota di Provinsi Lampung tahun 2003, 2010, dan 2014. Sedangkan peta penggunaan lahan Provinsi Lampung disajikan pada Gambar 2.

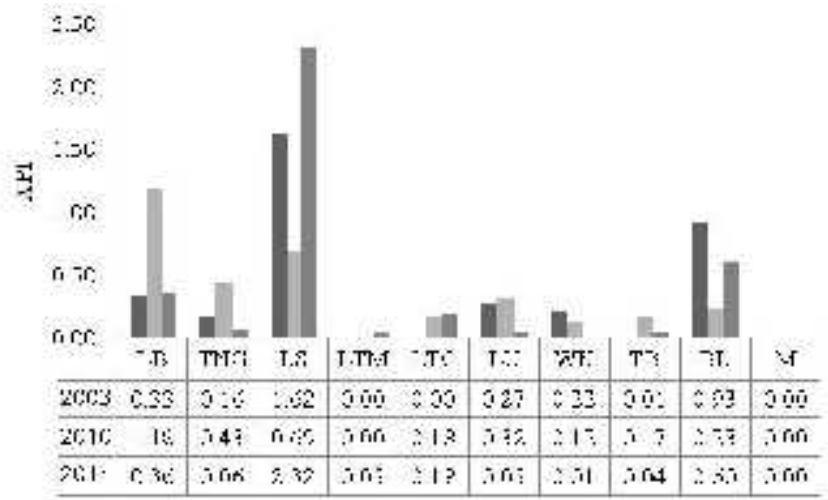

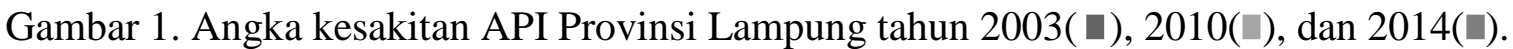

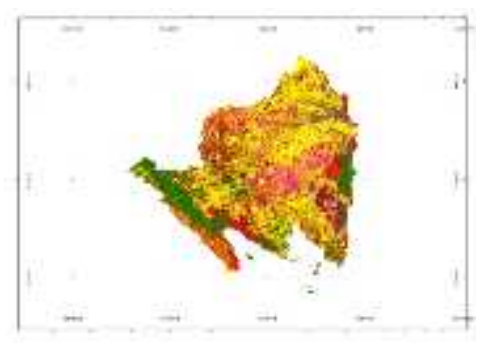

(a)

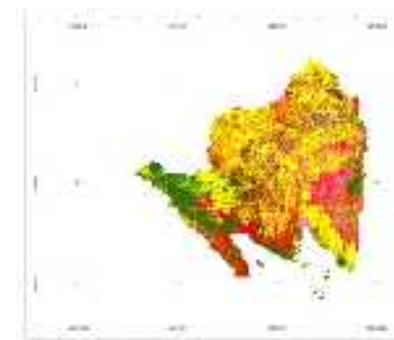

(b)

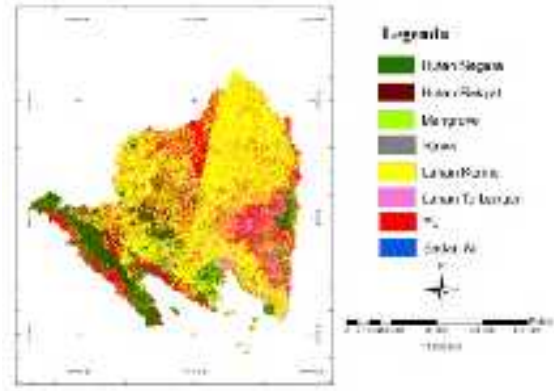

(c)

Gambar 2. Peta penggunaan lahan Provinsi Lampung tahun (a) 2002, (b) 2009, dan (c) 2014.

Adapun hasil optimasi parameter model dari penelitian ini disajikan pada Tabel 2.

Tabel 2. Ringkasan hasil optimasi parameter model pengaruh perubahan penggunaan lahan terhadap angka kesakitan malaria.

\begin{tabular}{|c|c|c|c|c|c|}
\hline Predictor & Simbol & $\operatorname{Coef}\left(\alpha_{n}\right)$ & SE Coef & $\mathbf{T}$ & $\mathbf{P}$ \\
\hline Constant & Co & $-0,448$ & 1,406 & $-0,32$ & 0,754 \\
\hline Hutan negara & $\mathrm{HN}$ & 0,02372 & 0,01459 & 1,63 & 0,125 \\
\hline Hutan rakyat & HR & $-0,00072$ & 0,01811 & $-0,04$ & 0,969 \\
\hline Hutan mangrove & MRV & 0,3727 & 0,1200 & 3,11 & $0,007^{(* * *)}$ \\
\hline Rawa & RW & $-0,12638$ & 0,04881 & $-2,59$ & $0,021^{(* *)}$ \\
\hline Lahan terbangun & LTER & 0,01426 & 0,01291 & 1,10 & 0,287 \\
\hline Lahan kering & LK & 0,00934 & 0,01396 & 0,67 & 0,514 \\
\hline Penggunaan lain & PL & $-0,02183$ & 0,02155 & $-1,01$ & 0,327 \\
\hline Curah hujan & $\mathrm{CH}$ & $-0,001141$ & 0,001129 & $-1,01$ & 0,328 \\
\hline Kepadatan penduduk & KPD & 0,0001954 & 0,0002323 & 0,84 & 0,414 \\
\hline Jumlah penduduk & JPD & 0,00000076 & 0,00006334 & 2,69 & $0,017^{(* *)}$ \\
\hline Tenaga kesehatan & TKS & $-0,0004560$ & 0,00006059 & $-1,84$ & $0,086^{(*)}$ \\
\hline Rumah tak layak & RTL & 0,00000693 & 0,01745 & 1,54 & 0,145 \\
\hline Urbanisme & $\mathrm{D}_{1 \_\mathrm{URBAN}}$ & $-0,5711$ & 0,9630 & $-0,59$ & 0,562 \\
\hline Fisiografis & $\mathrm{D}_{2} \mathrm{PGN}_{\mathrm{P}}$ & $-0,4977$ & 0,3071 & $-1,62$ & 0,126 \\
\hline $\mathrm{S}=0,314727$ & $\mathrm{R}-\mathrm{Sq}=82,1 \%$ & & $q(\operatorname{adj})=65,3$ & & \\
\hline
\end{tabular}

Sumber : Hasil Penelitian (2016). 


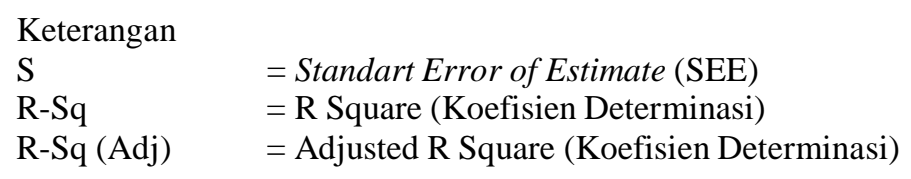

Catatan : (*) nyata pada taraf $10 \%,(* *)$ nyata pada taraf $5 \%,(* * *)$ nyata pada taraf $1 \%$.

Berdasarkan hasil optimasi parameter model dapat diketahui hubungan antara perubahan penggunaan lahan dan angka kesakitan malaria yang dirumuskan sebagai berikut:

$$
\begin{aligned}
{[\mathrm{Y}] \mathrm{it}=} & -0,45+0,0237[\mathrm{HN}]_{\mathrm{it}-1}-0,0007[\mathrm{HR}]_{\mathrm{it}-1}+0,373[\mathrm{MRV}]_{\mathrm{it}-1}-0,126[\mathrm{RW}]_{\mathrm{it}-1} \\
& +0,0143[\mathrm{LTER}]_{\mathrm{it}-1}+0,0093[\mathrm{LK}]_{\mathrm{it}-1}-0,0218[\mathrm{PL}]_{\mathrm{it}-1}-0,00114[\mathrm{CH}]_{\mathrm{it}-1} \\
& +0,000195[\mathrm{KPD}]_{\mathrm{it}}+0.000001[\mathrm{JPD}]_{\mathrm{it}}-0.000456[\mathrm{TKS}]_{\mathrm{it}}+0.000007[\mathrm{RTL}]_{\mathrm{it}} \\
& -0,571\left[\mathrm{D}_{1-} \mathrm{URBAN}\right]-0,498\left[\mathrm{D}_{2-} \mathrm{PGN}\right] \\
\text { Pvalue }= & 0.002
\end{aligned}
$$

Hasil uji $\mathrm{T}$ parsial berpengaruh nyata dengan Pvalue $=0,002$. Untuk regresi dengan lebih dari dua variabel bebas digunakan Adjusted R-Sq sebagai koefisien determinasi yang ditunjukan oleh nilai $\mathrm{R}-\mathrm{Sq}(\operatorname{adj})=65,3 \%$ artinya variabel $\mathrm{Y}$ yang dijelaskan oleh sekelompok variabel independen $\alpha_{1}, \alpha_{2}, \alpha_{3}, \alpha_{4}, \alpha_{5}, \alpha_{6}, \alpha_{7}, \alpha_{8}, \alpha_{9}, \alpha_{10}, \alpha_{11}, \alpha_{12}, \alpha_{13}, \alpha_{14}$ secara serentak sebesar $65,3 \%$ sedangkan sisanya $34,7 \%$ dijelaskan oleh variabel lain diluar model yang tidak diteliti. Hasil uji $\mathrm{F}$ yaitu peran masing-masing variabel terikat terhadap variabel bebas akan diuraikan sebagai berikut.

\section{Penggunaan Lahan}

Luas maksimum dan minimum hutan negara tahun 2002, 2009, dan 2014 masingmasing sebesar 51,85\% dan 0\% dengan rata-rata luas hutan negara sebesar 12,26\%. Sedangkan luas maksimum dan minimum hutan rakyat tahun 2002, 2009, dan 2014 masingmasing sebesar $41,05 \%$ dan $0 \%$ dengan rata-rata luas hutan rakyat sebesar $12,18 \%$. Pengaruh luas hutan negara terhadap angka kesakitan malaria di Provinsi Lampung memliki nilai koefisien positif yaitu 0,02372 . Dalam hal ini pengaruh luas tutupan hutan tidak berpengaruh nyata dengan angka kesakitan malaria seperti dicerminkan oleh nilai Pvalue sebesar 0,125 Lain halnya dengan pengaruh luas tutupan hutan rakyat yang ditunjukan oleh koefisien variabel [HR] sebesar $-0,00072$ yang berarti jika faktor lain tetap maka setiap penambahan luasan hutan rakyat sebesar $1 \%$ akan mengurangi 0,00072 jumlah kejadian malaria per 1000 penduduk. Meskipun dapat mengurangi angka kesakitan malaria namun luas hutan rakyat pengaruhnya tidak nyata (Pvalue=0,969). Raharjo (2011) menyatakan bahwa pembabatan hutan mungkin akan merubah penyebaran vektor penyakit sebanding dengan kontribusinya terhadap perubahan iklim dan perpindahan penduduk ke lahan hutan akan meningkatkan potensi terjadinya penyakit. Hasil penelitian di Peruvian dalam Raharjo (2011) menyebutkan batas penyebaran vektor malaria Anopheles menjadi dua ratus kali lebih tinggi setelah adanya pembabatan hutan.

Luas maksimum dan minimum hutan mangrove tahun 2002, 2009, dan 2014 masingmasing sebesar $2,73 \%$ dan $0 \%$ serta rata-rata luas hutan mangrove sebesar $0,23 \%$. Sedangkan Luas maksimum dan minimum rawa tahun 2002, 2009, dan 2014 masingmasing sebesar $9,49 \%$ dan $0 \%$ serta rata-rata luas rawa sebesar $1,06 \%$. Untuk luas tutupan hutan mangrove dan rawa berpengaruh nyata pada taraf $10 \%$ dengan Pvalue masing masing sebesar 0,007 dan 0,021. Seperti yang ditunjukan oleh koefisien variabel [RW] yaitu 0,12638 memberi arti bahwa setiap pertambahan $1 \%$ luas rawa akan menurunkan 0,12638 jumlah kejadian malaria per 1000 penduduk. Rawa merupakan salah satu habitat perkembangbiakan nyamuk Anopheles. 
Hasil penelitian Mading dan Kazwaini (2014) menunjukan bahwa perairan yang merupakan habitat perkembangbiakan termasuk jenis air tawar dan air payau. Selain rawa seperti embung, dam, kolam, dan badan-badan air buatan lainnya secara ekologis menyerupai rawa air tawar. Dari hasil cek lapangan rawa merupakan daerah sekitar mangrove namun letaknya relatif jauh dari pemukiman kemudian dikelola secaara intensif oleh masyarakat untuk budidaya perikanan darat dan cadangan pengairan lahan kering yang digunakan sebagai sumber air irigasi pada musim kemarau. Karena dikelola secara intensif maka siklus hidup nyamuk banyak mengalami gangguan.

Pengaruh luas tutupan hutan mangrove dengan koefisien variabel [MRV] yaitu 0,3727 yang menunjukan bahwa setiap pertambahan $1 \%$ luas hutan mangrove berpeluang meningkatkan angka kesakitan malaria 0,3727 jumlah kejadian malaria per 1000 penduduk. Dari hasil regresi variabel luas hutan mangrove berpengaruh nyata meningkatkan peluang kenaikan kejadian malaria di Provinsi Lampung seperti yang diungkapkan oleh Kazwaini dan Willa (2014) bahwa semakin banyak habitat perkembangbiakan maka kepadatan Anopheles spp. juga semakin tinggi.

Hutan mangrove berperan sebagai habitat nyamuk Anopheles sp., Putra (2014) menyatakan bahwa keberadaan hutan mangrove menyebabkan nyamuk tersebut cenderung tidak akan keluar dari hutan mangrove utamanya pada hutan mangrove yang belum terganggu. Namun hasil penelitian ini tidak membuktikan hal serupa, kemungkinan peluang meningkatnya kejadian malaria bisa disebabkan karena faktor bionomik nyamuk dimana faktor lingkungan sangat berperan, kondisi habitat nyamuk, serta kebiasaan dan perilaku manusia. Faktor lingkungan baik fisik maupun biologis akan mengatur keseimbangan populasi di alam apabila terjadi gangguan ekologis maka akan menyebabkan ledakan populasi nyamuk.

Hasil cek lapangan di wilayah pesisir terdapat pemukiman yang berada disekitar hutan mangrove sehingga meningkatkan resiko malaria karena peluang terinfeksi malaria juga berhubungan dengan kemampuan terbang nyamuk. Menurut Arsin dkk (2011) keberadaan suatu tempat perindukan nyamuk dapat mempengaruhi tingkat kepadatan di wilayah sekitarnya dalam radius yang cukup luas mengingat kemampuan terbang nyamuk Anopheles yang cukup jauh yaitu $0,5-3 \mathrm{~km}$ atau sekitar $2 \mathrm{~km}$, sehingga apabila dalam radius tersebut terdapat pemukiman maka tempat perindukan nyamuk tersebut merupakan faktor resiko bagi masyarakat di pemukiman tersebut untuk terkena penyakit malaria.

Luas maksimum dan minimum lahan terbangun tahun 2002, 2009, dan 2014 masingmasing sebesar $46,45 \%$ dan $1,79 \%$ serta rata-rata luas lahan terbangun sebesar $14,48 \%$. Pengaruh lahan terbangun terhadap angka kesakitan malaria di Provinsi Lampung memiliki nilai koefisien 0,01426 dengan Pvalue sebesar 0,287. Meskipun tidak berpengaruh nyata namun dengan setiap kenaikan luas lahan terbangun sebesar $1 \%$ akan meningkatkan 0,01426 kejadian malaria per 1000 penduduk di Provinsi Lampung. Dari hasil penelitian Mulyadi (2010) bahwa Anopheles Vagus tersebar disekitar pemukiman dengan jarak rumah 5-20 meter dengan ketinggian lokasi 1-18 mdpl. Sedangkan Anopheles kochi ditemukan hidup berkelompok dengan Anopheles farauti, Anopheles vagus, dan Anopheles punctulatus pada habitat disekitar pemukiman yang ditumbuhi ganggang dan tidak ada predator. Menurut Duarsa (2008) bahwa lingkungan geografis malaria telah berubah sebagai respon terhadap salah satunya yaitu pola penggunaan lahan. Setiap perubahan lingkungan yang terjadi akibat peristiwa alami atau melalui intervensi manusia akan merubah keseimbangan ekologi dalam konteks penyakit, host, vektor, dan jenis parasit dalam perkembangan dan transmisi penyakit.

Luas maksimum dan minimum lahan kering tahun 2002, 2009, dan 2014 masingmasing sebesar $86,81 \%$ dan $15,89 \%$ serta rata-rata luas lahan kering sebesar $59,89 \%$. Pertanian lahan kering meskipun tidak berpengaruh nyata $(\mathrm{P} v a l u e=0,514)$ dengan kejadian 
malaria di Provinsi Lampung tetapi memiliki nilai koefisien 0,00934 yang artinya setiap meningkatnya luas lahan kering dalam satuan luas $1 \%$ akan meningkatkan kejadian malaria 0,00934 kali semula.

Luas penggunaan lainnya tidak berpengaruh nyata dengan kejadian malaria di Provinsi Lampung (Pvalue = 0,327). Duarsa (2008) juga menjelaskan bahwa penggunaan lahan dapat mempengaruhi dan dipengaruhi kondisi politik dan ekonomi. Penggunaan lahan dan kondisi politik dan ekonomi dapat mempengaruhi keberadaan populasi manusia sebagai host sehingga dapat mempengaruhi resiko malaria. Menurut Munif (2009) lahan yang dikelola seperti persawahan biasanya ditempati berbagai jenis nyamuk yang berperan sebagai vektor. Beberapa jenis jentik nyamuk Anopheles lebih menyukai genang- genangan air yang baru karena belum ada musuh alami jentik tersebut.

Perubahan penggunaan lahan memiliki potensi menjadi habitat nyamuk Anopheles sebagai vektor malaria, karena nyamuk Anopheles cenderung menyukai tempat-tempat baru baik untuk berkembang biak maupun istirahat yang kondisi lingkungannya sesuai dengan kebutuhannya. Seperti yang diungkapkan oleh Munif (2009) bahwa kepentingan manusia dalam mengelola lahan pertanian, perikanan, perkebunan, maupun peternakan akan dimanfaatkan untuk perkembangbiakan larva nyamuk, sehingga berpengaruh terhadap kepadatan maupun perilaku nyamuk disuatu tempat.

\section{Curah hujan}

Analisis regresi menunjukan bahwa Pvalue variabel $[\mathrm{CH}]$ sebesar 0,328 yang berarti curah hujan tidak berpengaruh nyata dengan kejadian malaria. Seperti yang ditunjukan oleh koefisien variabel $[\mathrm{CH}]$ yaitu $-0,001141$ yang berarti bahwa setiap kenaikan curah hujan dalam satuan intensitas mm akan menurunkan 0,001141 kejadian malaria per 1000 penduduk. Hasil ini juga diperkuat dengan penelitian Mardiana dan Perwitasari (2014) yang menyatakan bahwa curah hujan yang tinggi akan bepengaruh terhadap habitat nyamuk dan menyebabkan nyamuk tidak dapat berkembang biak dengan sempurna sehingga penularan malaria akan rendah. Pada umumnya hujan akan memudahkan perkembangan nyamuk dan epidemis malaria namun besar kecilnya pengaruh tergantung pada jenis hujan, derasnya hujan, jumlah hari hujan, jenis vektor, dan jenis tempat perindukan (breeding places) (Duarsa, 2008).

\section{Kepadatan Penduduk dan Jumlah Penduduk}

Variabel koefisien kepadatan penduduk menunjukan nilai sebesar 0,0001954 berarti bahwa setiap kenaikan kepadatan penduduk persatuan jiwa $/ \mathrm{km}^{2}$ akan meningkatkan kejadian malaria sebesar 0,0001954. Namun variabel ini tidak berpengaruh nyata (Pvalue = 0,414). Hal tersebut terjadi akibat jumlah penduduk yang semakin meningkat dengan luas wilayah yang tetap sehingga memudahkan penularan penyakit malaria. Jumlah penduduk berpengaruh nyata dengan kejadian malaria di Provinsi Lampung dengan Pvalue sebesar 0,017 dengan nilai koefisien sebesar 0,00000076 bahwa setiap bertambahnya jumlah penduduk per satu satuan akan meningkatan kejadian malaria sebesar 0,00000076.

\section{Tenaga Kesehatan}

Nilai koefisien variabel tenaga kesehatan yaitu $-0,0004560$ sehingga pengaruhnya terhadap kejadian malaria yaitu setiap meningkatnya jumlah tenaga kesehatan per satu satuan akan menurunkan -0,0004560 kejadian malaria di Provinsi Lampung, pengaruh ini sangat nyata dengan Pvalue sebesar 0,086. Peran petugas kesehatan sangat menentukan dalam memutus rantai siklus hidup nyamuk Anopheles, salah satu bentuk kebijakan petugas kesehatan adalah memberikan penyuluhan kesehatan tentang pemberantasan sarang nyamuk penyebab malaria. Penyuluhan kesehatan bertujuan agar masyarakat menyadari tentang 
penanggulangan dan pemberantasan malaria sehingga mengubah perilaku untuk hidup bersih dan sehat (Nurhadi dkk, 2011).

\section{Faktor Resiko Lingkungan Perumahan}

Pengaruh faktor resiko lingkungan seperti kondisi rumah tak layak bisa jadi berpengaruh terhadap angka kesakitan malaria di Provinsi Lampung. Berdasarkan Kementerian Sosial Republik Indonesia (2014) kriteria rumah tidak layak huni dilihat dari luas rumah (kurang dari $8 \mathrm{~m}^{2} /$ orang), atap dibuat dari bahan yang mudah rusak/lapuk seperti : rumbia, seng, ilalang, ijuk, serta genteng, jenis dinding (bilik, papan, bamboo, kulit kayu dalam kondisi rusak), dan jenis lantai (tanah, papan, bamboo, semen dalam kondisi rusak).

Dari hasil analisis regresi faktor rumah tak layak tidak berpengaruh nyata terhadap kejadian malaria sebagaimana ditunjukan oleh Pvalue sebesar 0,145. Namun koefisien variabel [RTL] yaitu 0,00000693 memberi makna bahwa masyarakat dengan kondisi rumah tak layak memiliki resiko untuk terinfeksi malaria 0,00000693 kali semula dari pada masyarakat yang memiliki kondisi rumah layak. Hasil penelitian ini didukung oleh penelitian Ernawati dkk (2011) bahwa faktor resiko kondisi perumahan menunjukan bahwa makin tidak baik kondisi perumahan, semakin besar resiko individu yang tinggal dirumah tersebut untuk terinfeksi malaria.

\section{Urbanisme}

Peran variabel [D,_URBAN] meskipun tidak berpengaruh nyata dengan kejadian malaria di Provinsi Lampung (Pvalue $=0,562$ ) tetapi memiliki nilai koefisien sebesar $-0,5711$, dengan demikian dapat dijelaskan bahwa masyarakat bertempat tinggal di wilayah berstatus kota memiliki potensi lebih rendah terjangkit penyakit malaria 0,5711 dari masyarakat yang bertempat tinggal di wilayah berstatus kabupaten di Provinsi Lampung. Hasil ini diperkuat oleh Perhimpunan Dokter Spesialis Penyakit Dalam Indonesia (PAPDI) (2003) yang menyatakan bahwa malaria menduduki urutan kedelapan dari 10 besar penyakit penyebab utama kematian di Indonesia dengan angka kematian di perkotaan 0,7\% dan di pedesaan 1,7\%. Ariati dkk (2008) juga menyatakan bahwa daerah endemik malaria di Indonesia terdapat di daerah pedesaan dengan keadaan sosial ekonomi yang rendah, transportasi dan komunikasi yang relatif rendah.

\section{Fisiografis}

Wilayah yang terletak dibentang lahan pegunungan tidak berpengaruh nyata dengan kejadian malaria $(\mathrm{P}$ value $=0,126)$ dan memiliki nilai koefisien $\left[\mathrm{D}_{2} \_\mathrm{PGN}\right]$ sebesar $-0,498$ dengan demikian bahwa wilayah yang terletak dibentang lahan pegunungan berpotensi mengalami kejadian malaria lebih rendah 0,498 dari wilayah yang tidak berada di bentang lahan pegunungan. Hal tersebut berkaitan dengan ketinggian tempat, malaria akan berkurang pada ketinggian yang semakin bertambah. Berdasarkan Departemen Kesehatan Republik Indonesia (2003) dalam Arsin (2012) terjadi hubungan yang erat antara pola penyebaran malaria terhadap ketinggian suatu tempat pola penyebaran tersebut semakin luas terjadi pada wilayah yang berada pada ketinggian dibawah 1000 mdpl dan semakin sedikit atau tidak ditemukan pada ketinggian diatas $1000 \mathrm{mdpl}$, hal ini disebabkan oleh perilaku nyamuk Anopheles sp. yang senang hidup di dataran rendah.

\section{KESIMPULAN}

Hasil penelitian membuktikan bahwa perubahan penggunaan lahan hutan mangrove dan rawa menyebabkan gangguan ekologis yang berdampak pada angka kesakitan malaria. 
Variabel yang berpengaruh nyata positif terhadap angka kesakitan malaria yaitu luas hutan mangrove (Coef $\left.\alpha_{\mathrm{MRV}}=0,3727\right)$ dan jumlah penduduk $\left(\right.$ Coef $\left.\alpha_{\mathrm{JPD}}=0,00000076\right)$ sedangkan variabel yang berpengaruh nyata negatif yaitu luas rawa (Coef $\alpha_{\mathrm{RW}}=-0,12638$ ) dan tenaga kesehatan (Coef $\left.\alpha_{\mathrm{TKS}}=-0,0004560\right)$. Variabel yang tidak berpengaruh nyata terhadap angka kesakitan malaria antara lain hutan negara, hutan rakyat, lahan terbangun, lahan kering, penggunaan lain, kepadatan penduduk, curah hujan, rumah tak layak, urbanisme, dan fisiografis.

\section{SARAN}

Disarankan untuk melakukan penelitian serupa menggunakan citra satelit dengan resolusi yang lebih tinggi. Disarankan pula dengan unit analisis wilayah kabupaten/kota.

\section{DAFTAR PUSTAKA}

Ariati, Y., Wigati, H., Andris, S., Sukowati. 2008. Bioekologi vektor malaria nyamuk Anopheles sundaicus di Kecamatan Nongsa, Kota Batam, tahun 2008. Jurnal Ekologi Kesehatan. 10(1):29-37.

Arsin, A., I., Muslimin, R., Nawi. 2011. Pola spasial dan analisis kejadian malaria di Pulau Kapoposang Kab. Pangkep tahun 2011. Jurnal Ilmiah Aktualita. 3(3):28-35.

Arsin, A.A. 2012. Malaria di Indonesia Tinjauan Aspek Epidemologi. Buku. Masagena Press. Makasar. 187 p.

Badan Pusat Statistik Provinsi Lampung. 2005. Lampung dalam Angka 2004/2005. Bandar Lampung. 597 p.

Badan Pusat Statistik Provinsi Lampung. 2011. Lampung dalam Angka 2011. Bandar Lampung. 525 p.

Badan Pusat Statistik Provinsi Lampung. 2015. Lampung dalam Angka 2015. Bandar Lampung. $415 \mathrm{p}$.

Bakri, S., T., Santoso, D.W.S.R., Wardani, A, Setiawan. 2015. Pengaruh perubahan penggunaan lahan terhadap angka kesakitan malaria : Studi di Provinsi Lampung. Proposal.

Center for Soil Research (CSR). 1989. Land Resource Evaluation and Planning Project I. Board of Research and Development Dept. of Agriculture RI. Bogor. Map of Soil and Land Unit, sheets 1010-1012, 1110-112.

Dinas Kesehatan Provinsi Lampung. 2004. Profil Kesehatan Provinsi Lampung tahun 2003. Buku. Pemerintah Daerah Provinsi Lampung. Bandar Lampung. 69 p.

Dinas Kesehatan Provinsi Lampung. 2011. Profil Kesehatan Provinsi Lampung tahun 2010. Buku. Pemerintah Daerah Provinsi Lampung. Bandar Lampung. 195 p.

Dinas Kesehatan Provinsi Lampung. 2014. Profil Kesehatan Provinsi Lampung tahun 2013. Buku. Pemerintah Daerah Provinsi Lampung. Bandar Lampung. 165 p.

Dinas Kesehatan Provinsi Lampung. 2015. Profil Kesehatan Provinsi Lampung tahun 2014. Buku. Pemerintah Daerah Provinsi Lampung. Bandar Lampung. 149 p.

Duarsa, A.B.S. 2008. Dampak pemanasan global terhadap resiko terjadinya malaria. Jurnal Kesehatan Masyarakat. 2(2):64-68.

Ernawati, K., B. Soesilo, A. Duarsa, Rifqatussa'adah. 2011. Hubungan faktor resiko individu dan lingkungan rumah dengan malaria di Punduh Pedada Kabupaten Pesawaran Provinsi Lampung Indonesia 2010. Makara Kesehatan. 15(2):51—57. 
Kazwaini, M. dan R.W., Willa. 2015. Korelasi kepadatan Anopheles spp. dengan curah hujan serta status vector malaria pada berbagai tipe geografi di Kabupaten Sumba Timur, Provinsi Nusa Tenggara Timur. Buletin Penelitian Kesehatan. 4(3):77-88.

Kementerian Kehutanan. 2013. Statistik Kehutanan Indonesia. Buku. Kementrian Kehutanan. Jakarta. 307 p.

Kementerian Sosial Republik Indonesia. 2014. Pedoman Rehabilitasi Sosial Rumah Tidak Layak Huni (RS-RLTH) dan Sarana Lingkungan tahun 2014. Buku. Direktorat Jendral Pemberdayaan Sosial dan Penanggulangan Kemiskinan. Jakarta Pusat. 50 p.

Mading, M., dan Kazwaini, M. 2014. Ekologi Anopheles spp. di Kabupaten Lombok Tengah. Jurnal Aspirator. 6(1):13-20.

Mardiana, dan D. Perwitasari. 2014. Insiden malaria dan pola iklim di Kabupaten Kapuas Provinsi Kalimantan Tengah dan Kabupaten Sumba Barat Provinsi Nusa Tenggara Timur Indonesia tahun 2005-2009. Jurnal Ekologi Kesehatan. 13(1):59_ 70.

Mulyadi. 2010. Distribusi spasial dan karakteristik habitat perkembangan Anopheles spp. serta peranannya dalam penularan malaria di Desa Doro Kabupaten Halmahera Selatan Provinsi Maluku Utara. Tesis. Institut Pertanian Bogor. Bogor.

Munif, A. 2009. Nyamuk vektor malaria dan hubungannya dengan aktivitas kehidupan manusia di Indonesia. Jurnal Aspirator. 1(2):94-102.

Nurhadi, S., Notosoedarmo, M., Martosupono. 2011. Pengaruh lingkungan terhadap kejadian malaria di Kabupaten Mimika. Prosiding Seminar Nasional VIII Pendidikan Biologi. 8(1).

Perhimpunan Dokter Spesialis Penyakit Dalam Indonesia (PAPDI). 2003. Konsensus Penanganan Malaria 2003. 7-10 p.

Putra, A.K. 2014. Peranan ekosistem hutan mangrove terhadap ketahanan penyakit malaria: studi di Kecamatan Labuhan Maringgai Kabupaten Lampung Timur. Skripsi. Universitas Lampung. Bandar Lampung.

Raharjo, M. 2011. Malaria vulnerability index (mvi) untuk manajemen resiko dampak perubahan iklim global terhadap ledakan malaria di Indonesia. Jurnal Vektor dan Resevoir Penyakit. 3(1):54-58.

Yudhastuti, R. 2008. Gambaran faktor lingkungan daerah endemis malariadi Daerah berbatasan (Kabupaten Tulungagung dengan Kabupaten Trenggalek). Jurnal Kesehatan Lingkungan. 4(2):9-20. 